\title{
Cochrane
}

Library

Cochrane Database of Systematic Reviews

\section{Ginkgo biloba extract for age-related macular degeneration} (Review)

\section{Evans JR}

Evans JR.

Ginkgo biloba extract for age-related macular degeneration.

Cochrane Database of Systematic Reviews 2013, Issue 1. Art. No.: CD001775.

DOI: 10.1002/14651858.CD001775.pub2.

www.cochranelibrary.com 
TABLE OF CONTENTS

HEADER 1

ABSTRACT

PLAIN LANGUAGE SUMMARY

BACKGROUND

OBJECTIVES

METHODS

RESULTS

Figure 1.

Figure 2.

DISCUSSION

AUTHORS' CONCLUSIONS

ACKNOWLEDGEMENTS

REFERENCES

CHARACTERISTICS OF STUDIES

APPENDICES

WHAT'S NEW

HISTORY

CONTRIBUTIONS OF AUTHORS

DECLARATIONS OF INTEREST

INDEX TERMS 
[Intervention Review]

\section{Ginkgo biloba extract for age-related macular degeneration}

Jennifer R Evans ${ }^{1}$

${ }^{1}$ Cochrane Eyes and Vision Group, ICEH, London School of Hygiene \& Tropical Medicine, London, UK

Contact address: Jennifer R Evans, Cochrane Eyes and Vision Group, ICEH, London School of Hygiene \& Tropical Medicine, Keppel Street, London, WC1E 7HT, UK. jennifer.evans@lshtm.ac.uk.

Editorial group: Cochrane Eyes and Vision Group

Publication status and date: New search for studies and content updated (no change to conclusions), published in Issue 1, 2013.

Citation: Evans JR. Ginkgo biloba extract for age-related macular degeneration. Cochrane Database of Systematic Reviews 2013 , Issue 1. Art. No.: CD001775. DOI: 10.1002/14651858.CD001775.pub2.

Copyright $\odot 2013$ The Cochrane Collaboration. Published by John Wiley \& Sons, Ltd.

\section{A B S T R A C T}

\section{Background}

Ginkgo is used in the treatment of peripheral vascular disease and 'cerebral insufficiency'. It is thought to have several potential mechanisms of action including increased blood flow, platelet activating factor antagonism, and prevention of membrane damage caused by free radicals. Vascular factors and oxidative damage are thought to be two potential mechanisms in the pathology of age-related macular degeneration (AMD).

\section{Objectives}

The objective of this review was to determine the effect of Ginkgo biloba extract on the progression of AMD.

\section{Search methods}

We searched CENTRAL (which contains the Cochrane Eyes and Vision Group Trials Register) (The Cochrane Library 2012, Issue 10), Ovid MEDLINE, Ovid MEDLINE In-Process and Other Non-Indexed Citations, Ovid MEDLINE Daily, Ovid OLDMEDLINE (January 1946 to October 2012), EMBASE (January 1980 to October 2012), Allied and Complementary Medicine Database (AMED) (January 1985 to October 2012), OpenGrey (System for Information on Grey Literature in Europe) (www.opengrey.eu/), the metaRegister of Controlled Trials (mRCT) (www.controlled-trials.com), ClinicalTrials.gov (www.clinicaltrials.gov) and the WHO International Clinical Trials Registry Platform (ICTRP) (www.who.int/ictrp/search/en). We did not use any date or language restrictions in the electronic searches for trials. We last searched the electronic databases on 5 October 2012. We searched the reference lists of identified reports and the Science Citation Index. We also contacted investigators of included studies for additional information.

\section{Selection criteria}

All randomised trials in people with AMD where Ginkgo biloba extract had been compared to control were included.

\section{Data collection and analysis}

The review author extracted data using a standardised form. The data were verified with the trial investigators. Trial quality was assessed.

\section{Main results}

Two published trials were identified that randomised a total of 119 people. In one study conducted in France, 20 people were randomly allocated to Gingko biloba extract EGb $76180 \mathrm{mg}$ twice daily or placebo. In the other study conducted in Germany, 99 people were randomly allocated to two different doses of Ginkgo biloba extract EGb 761 ( $240 \mathrm{mg}$ per day and $60 \mathrm{mg}$ per day). Treatment duration in both studies was six months. Both trials reported some positive effects of Ginkgo biloba on vision however their results could not be pooled. Adverse effects and quality of life for people with AMD were not reported. 


\section{Authors' conclusions}

The question as to whether people with AMD should take Ginkgo biloba extract to prevent progression of the disease has not been answered by research to date. Two small trials have suggested possible benefit of Gingko biloba on vision and further trials are warranted. Ginkgo biloba is widely used in China, Germany, and France. Future trials should be larger, and last longer, in order to provide a more robust measure of the effect of Gingko biloba extract on AMD.

\section{PLAIN LANGUAGE SUMMARY}

\section{Use of Gingko biloba, an extract from the leaves of the maidenhair tree, for slowing the progression of age-related macular} degeneration

Age-related macular degeneration (AMD) is a condition affecting the central area of the retina (the back of the eye). The retina can deteriorate with age and some people get lesions that lead to loss of central vision. Gingko biloba, extracted from the leaves of the maidenhair tree, is used in Chinese herbal medicine to treat a variety of medical conditions, in particular circulatory problems. Ginkgo biloba extract contains two constituents (flavonoids and terpenoids) which have antioxidant properties. It is believed these may help to slow down the progression of AMD. The author identified two small randomised controlled studies (with a total of 119 participants); one in France and one in Germany. One trial compared Gingko biloba to placebo and the other compared two different doses of the extract. Although both trials reported some positive effects of Ginkgo biloba on vision, the trials were small and of short duration. Adverse effects and quality of life were not assessed. The overall conclusion of this review is that current research has not answered the question as to whether Ginkgo biloba is of benefit to people with AMD. Future trials need to include a larger number of participants and be conducted over a longer time. 


\section{B A C K G R O U N D}

\section{Description of the condition}

Age-related macular degeneration is a disease affecting the central area of the retina (the macula). In the early stages of the disease, lipid material accumulates in deposits underneath the retinal pigment epithelium. These deposits are known as drusen and can be seen as pale yellow spots on the retina. The pigment of the retinal epithelium may become disturbed with areas of hyperpigmentation and hypopigmentation. In the later stages of the disease, the retinal pigment epithelium may atrophy completely. This loss can occur in small focal areas or it can be widespread (geographic). In some cases, new blood vessels grow under the retinal pigment epithelium and occasionally into the subretinal space (exudative or neovascular AMD). Haemorrhage can occur, which often results in increased scarring of the retina.

The early stages of the disease are in general asymptomatic. In the later stages there may be considerable distortion of vision and complete loss of visual function, particularly in the central area of vision. Population-based studies suggest that, in people 75 years and older, approximately $30 \%$ have early signs of the disease and $7 \%$ have late stage disease (Klein 1992). It is the most common cause of blindness and visual impairment in industrialised countries. For example, in the UK over 30,000 people are registered as blind or partially sighted annually, half of whom have lost their vision due to macular degeneration (Evans 1996). Currently there is no treatment which can restore vision in AMD.

\section{Description of the intervention}

The use of extracts from the leaves of Ginkgo biloba (maidenhair tree) for medical purposes originated in China; the extracts are commonly prescribed in Germany and France (Kleijnen 1992). There are two main extracts that have similar constituents: EGb 761 , which consists of $24 \%$ ginkgo-flavone glycosides and $6 \%$ terpenoids; and LI1370, which has $25 \%$ ginkgo-flavone glycosides and $6 \%$ terpenoids.

\section{How the intervention might work}

Ginkgo is used in the treatment of peripheral vascular disease and 'cerebral insufficiency'. It is thought to have several potential mechanisms of action:

1. increased blood flow;

2. platelet activating factor antagonism;

3. prevention of membrane damage caused by free radicals.

Vascular factors and oxidative damage are thought to be two potential mechanisms in the pathology of AMD. Animal studies suggest that EGb 761 protects mammalian retinal cells from damage (Droy-Lefaix 1993; Droy-Lefaix 1995; Pritz-Hohmeier 1994).

\section{Why it is important to do this review}

Complementary therapies such as Ginkgo biloba can be widely adopted without adequate evidence of potential benefits and harms. It is important to have a systematic assessment of the evidence for use of Ginkgo biloba for AMD, to inform patients and clinicians.

\section{O B JECTIVES}

The objective of this review was to assess the effect of Ginkgo biloba extract on the progression of AMD and to evaluate any potential harmful effects.

\section{METHODS}

\section{Criteria for considering studies for this review Types of studies}

Only randomised controlled trials were eligible for inclusion in this review.

\section{Types of participants}

Participants in the trials were people with AMD in one or both eyes.

\section{Types of interventions}

Trials in which the intervention was Ginkgo biloba, compared to placebo or no intervention, were included. Two main extracts of Ginkgo were considered: EGb 761 and LI1370.

\section{Types of outcome measures}

The following outcomes were used:

1. number of participants with disease progression;

2. number of participants with new visual loss due to AMD;

3. quality of life measures;

4. any adverse outcomes reported.

The definitions used were as follows.

AMD: this was taken as defined by trial investigators. It is commonly defined as: in the macular area 3000 microns diameter from fovea, drusen with or without pigmentary abnormalities or geographic atrophy or characteristic choroidal neovascularisation with no other cause.

Progression of disease: development of drusen, geographic atrophy, or growth or progression of new vessels in the retina.

Visual loss: any well-defined outcome based on visual acuity was used, depending on the way in which authors presented trial data.

Quality of life: any validated measurement scale which aims to measure the impact of visual function loss on quality of life of participants.

\section{Search methods for identification of studies}

\section{Electronic searches}

We searched the Cochrane Central Register of Controlled Trials (CENTRAL) 2012, Issue 10, part of The Cochrane Library. www.thecochranelibrary.com (accessed 5 October 2012), Ovid MEDLINE, Ovid MEDLINE In-Process and Other Non-Indexed Citations, Ovid MEDLINE Daily, Ovid OLDMEDLINE (January 1946 to October 2012), EMBASE (January 1980 to October 2012), Allied and Complementary Medicine Database (AMED) (January 1985 to October 2012), OpenGrey (System for Information on Grey Literature in Europe) (www.opengrey.eu/), the metaRegister of Controlled Trials (mRCT) (www.controlledtrials.com), ClinicalTrials.gov (www.clinicaltrials.gov) and the 
WHO International Clinical Trials Registry Platform (ICTRP) (www.who.int/ictrp/search/en). We did not use any date or language restrictions in the electronic searches for trials. We last searched the electronic databases on 5 October 2012.

The UK Clinical Trials Gateway is no longer being searched for this review as the other trials websites which are being searched are more comprehensive.

See: Appendices for details of search strategies for CENTRAL (Appendix 1), MEDLINE (Appendix 2), EMBASE (Appendix 3), OpenGrey (Appendix 4), AMED (Appendix 5), mRCT (Appendix 6), ClinicalTrials.gov (Appendix 7) and the ICTRP (Appendix 8).

We reviewed all the possible trials identified that included a Ginkgo biloba intervention to see if participants with macular degeneration were specifically included.

\section{Searching other resources}

We searched the reference lists of identified trial reports to find additional trials. We used the Science Citation Index to find studies which had cited the identified trials. Investigators were contacted to identify additional published and unpublished studies. We searched the database of randomised controlled trials compiled by the Cochrane Complementary Medicine Field in the initial search for the review.

\section{Data collection and analysis}

\section{Selection of studies}

The author reviewed the titles and abstracts of all reports of trials identified by the electronic searching. The full text hard copies of possible trials of the effect of Ginkgo biloba on AMD were obtained. Relevant studies were selected according to the definitions in the 'Criteria for considering studies for this review'.

\section{Data extraction and management}

The author extracted data using a standardised form developed by the Cochrane Eyes and Vision Group. These data were verified with the trial investigators.

\section{Assessment of risk of bias in included studies}

This was a new feature for the update in 2009. Assessment of the risk of bias was done using the Cochrane Collaboration's tool for assessing the risk of bias as described in Chapter 8 of the Cochrane Handbook for Systematic Reviews of Interventions (Higgins 2011).

The extent to which bias could have been introduced in the following aspects of study design and execution was assessed: sequence generation, allocation concealment, blinding (masking), incomplete outcome data, and selective outcome reporting.

\section{Measures of treatment effect}

The risk ratio was used for dichotomous outcome measures (for example, ratio of clinical improvement to no clinical improvement). The mean difference was used for continuous outcome measures, such as visual acuity.

\section{Unit of analysis issues}

Ginkgo biloba extract is applied to the person but information on two eyes can be reported. There are a variety of ways of dealing with this but in both included studies the investigators reported results for the worst affected eye only.

\section{Assessment of reporting biases}

Currently, with only two trials identified, it is not possible to assess the role of publication bias.

\section{Data synthesis}

No summary measure was calculated because the two trials considered different comparisons (EGb 761: $160 \mathrm{mg} /$ day versus placebo; and EGb 761: $240 \mathrm{mg} /$ day versus $60 \mathrm{mg} /$ day) and reported data in different formats.

\section{RESULTS}

\section{Description of studies}

\section{Results of the search}

The electronic searches identified 616 titles and abstracts. We screened the titles and abstracts according to the criteria outlined above and found one trial of AMD (Lebuisson 1986). A further trial was identified (Fies 2002) by one of the peer reviewers of this review. The original searches were performed in December 1998 and the searches were updated in: February and September 2000 December 2001, January 2006, and December 2008. No new trials were found in the updated searches.

An update search was done in October 2012 which yielded eight new records. The Trials Search Co-ordinator scanned the search results and removed three references which were not relevant to the scope of the review. The review author screened the title and abstracts of the remaining five references and rejected them as not eligible for inclusion in the review.

\section{Included studies}

Details can be found in the 'Characteristics of included studies' table.

\section{Types of participants}

In the Lebuisson 1986 trial participants were people aged over 55 years. The participants were outpatients attending an eye clinic. Similarly in the study by Fies 2002 participants were outpatient attendees aged 59 years and above (average age approximately 75 years).

\section{Types of intervention}

Lebuisson 1986 compared 80 mg twice daily (160 mg) Ginkgo biloba extract EGb 761 with a placebo which the authors stated had the same appearance, smell, and taste. Treatment lasted six months. Fies 2002 compared 240 mg EGb 761 daily with 60 mg daily. Treatment and follow up lasted 24 weeks.

\section{Types of outcome measures}

Outcome measures included: distance and near visual acuity; visual field; and clinical assessment of progression of disease. These were measured at the end of the six-month treatment period.

\section{Risk of bias in included studies}

See Figure 1 and Figure 2. 
Figure 1. Methodological quality graph: review authors' judgements about each methodological quality item presented as percentages across all included studies.

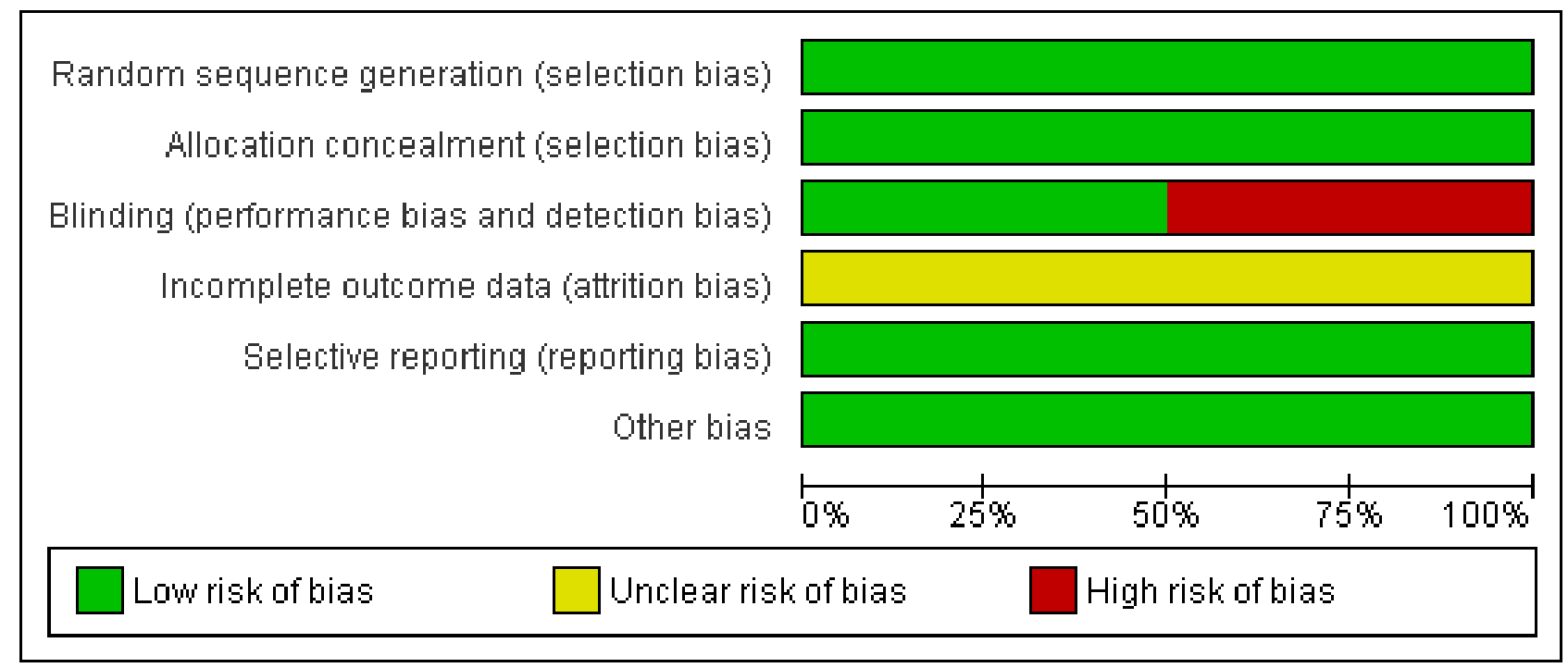

Figure 2. Methodological quality summary: review authors' judgements about each methodological quality item for each included study.

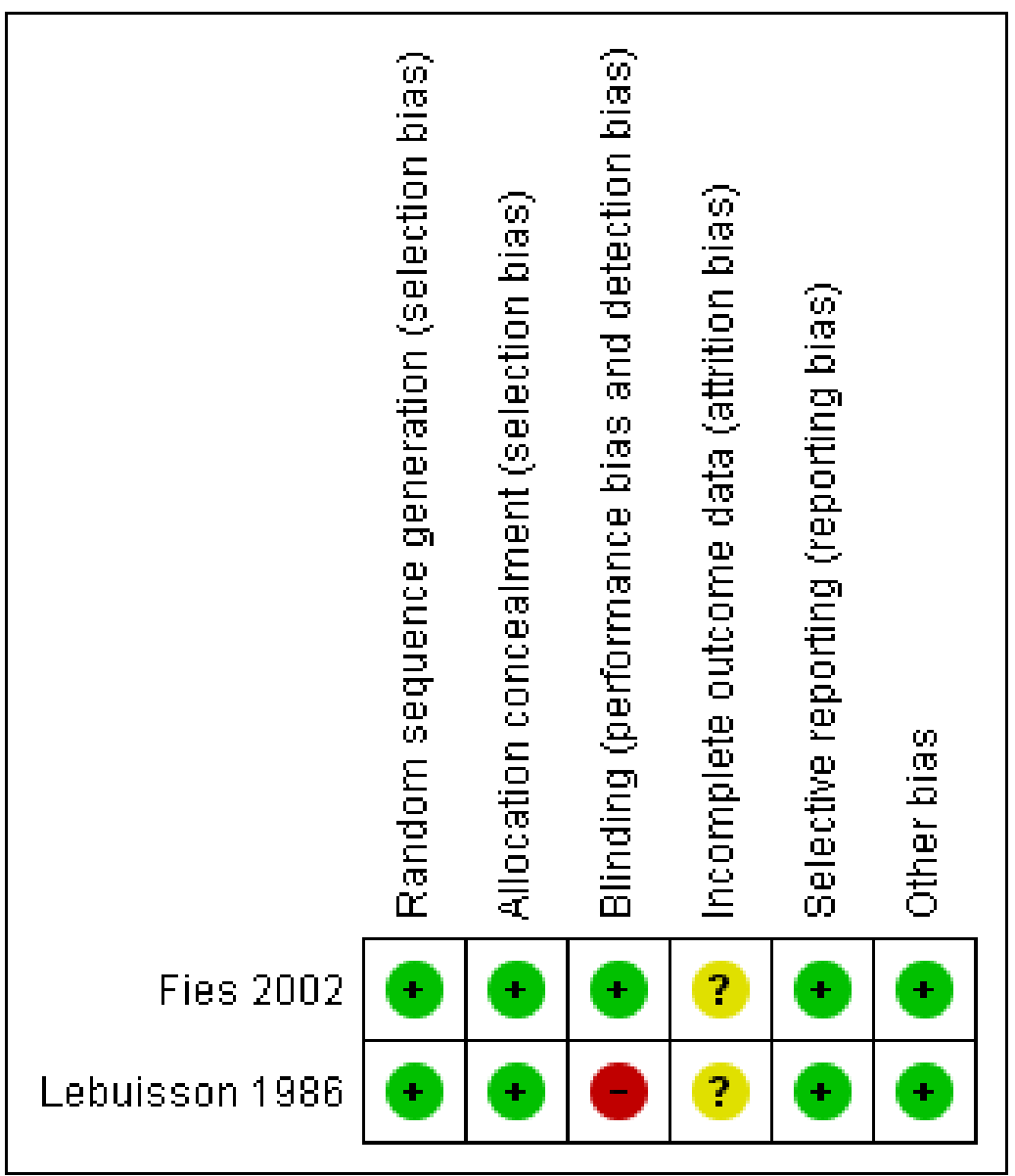




\section{Allocation}

Lebuisson 1986 was randomised appropriately by use of random number tables. Whether or not the allocation was properly concealed was not reported, however, the fact that the study was placebo-controlled and the placebo was reported to be similar to the active treatment suggests that the allocation was likely to be concealed.

In Fies 2002 a randomisation list was prepared by a validated EDPrandom number generator. The numbers one to 100 were allocated randomly to the treatment groups before the start of the study. Participants received this number in consecutive order of inclusion.

\section{Blinding}

In Lebuisson 1986 the assessment of outcome was not masked. The placebo was prepared to have the same appearance, smell, and taste; however, Ginkgo biloba has a characteristic bitter taste that is difficult to mask (Knipschild 1998).

In Fies 2002 the investigators and participants were masked during the study.

\section{Incomplete outcome data}

In Lebuisson 198620 participants were followed up for six months but it was not clear if more participants were recruited initially. In Fies 2002 there were dropouts reported but it was not clear exactly how these were dealt with; the report suggested that an intentionto-treat analysis was done.

\section{Selective reporting}

No suggestion of selective reporting as key outcomes, visual acuity and clinical progression, were reported in both studies.

\section{Effects of interventions}

Lebuisson 1986: 10 people were included in each treatment group. Acuity (measured using a Snellen chart) improved in both groups during the six months of treatment but to a greater extent in the Ginkgo treated group. In the treatment group, average initial visual acuity was $3.8 / 10$ (standard deviation (SD) $0.6 / 10$ ). At the end of six months the average acuity was $6.1 / 10$ (SD 0.8/10), an average improvement in vision of $2.3 / 10$ (SD $0.7 / 10$ ). In the placebo group, average initial visual acuity was $4.8 / 10$ (SD 0.9/10). At the end of six months the average acuity was 5.4/10 (SD 1.06/10), an average improvement in vision of $0.6 / 10$ (SD 0.7/10). This gives a mean difference of $1.7 / 10$ (95\% confidence interval (CI) 0.12 to 0.22 ).

Tests of association for near vision and visual field were stated to be not statistically significant. Clinical observation suggested that nine out of 10 people in the treatment group improved compared to two in the control group (risk ratio (RR) $4.5,95 \% \mathrm{Cl} 1.28$ to 15.81).

Fies 2002: 50 people were allocated to $240 \mathrm{mg} /$ day and 49 people to $60 \mathrm{mg} /$ day. Both groups improved in terms of visual acuity over the treatment period. There was no statistically significant difference in average visual acuity at the end of the study (mean difference in acuity at end of study $0.05,95 \% \mathrm{Cl}-0.30$ to 0.13 ). Greater numbers of the high dose group improved by 0.2 or more although this difference was not statistically significant (RR 1.85, 95\% Cl 0.91 to 3.75).

\section{Adverse effects}

Fies 2002: one person in the high dose group reported a headache; one person in the high dose group had blood in the stools; and two people in the low dose group experienced abdominal pain.

\section{DISCUSSION}

\section{Summary of main results}

Two trials were identified that investigated the effect of Ginkgo biloba on AMD. Both trials reported some positive effects of Ginkgo biloba on vision. However, in both studies the visual acuity of participants improved in both treatment and control groups.

With only two relatively small trials reported, this review does not provide good systematic assessment of any potentially harmful effects of Gingko biloba. Adverse effects related to bleeding, such as subdural haematoma and hyphaema, have been reported (Rosenblatt 1997; Rowin 1996). There have been several Cochrane reviews of Ginkgo biloba for other conditions which include a greater number of trials and, therefore, provide better evidence of any potential harms (Birks 2009; Hilton 2004; Zeng 2005). None of these reviews have identified serious major adverse effects associated with using Ginkgo biloba.

\section{Overall completeness and applicability of evidence}

The studies reported were too small and short in duration to answer conclusively the question as to whether Ginkgo biloba is of benefit to people with AMD.

\section{Quality of the evidence}

As Gingko biloba is a pharmaceutical treatment there is the potential to mask active treatment. However, Ginkgo biloba has a characteristic bitter taste that is difficult to mask (Knipschild 1998). This issue was not considered in the placebo-controlled trial. Outcome assessors were not masked and the only clinical outcome reported did not have a clear case definition.

\section{Potential biases in the review process}

Publication bias could not be assessed as only two published trials were identified.

\section{AUTHORS' CONCLUSIONS}

\section{Implications for practice}

Current research has not answered the question as to whether Ginkgo biloba is of benefit to people with age-related macular degeneration.

\section{Implications for research}

Two small trials have suggested possible benefit of Gingko biloba on vision and further trials are warranted. Ginkgo biloba is widely used in China, Germany, and France. Future trials should be larger, and last longer, in order to provide a more robust measure of the effect on AMD. Care needs to be taken to provide a placebo control that has a similar bitter taste as the active ingredient.

\section{ACKNOWLEDGEMENTS}

I am grateful to: 
- Dr Lebuisson for responding to queries about the French trial - Jos Kleijnen and Giselle Soubrane for peer review comments;
- The Eyes and Vision Group for devising and running the search strategies. 


\section{REFERE N CES}

\section{References to studies included in this review}

Fies 2002 \{published data only\}

* Fies P, Dienel A. Ginkgo extract in impaired vision--treatment with special extract EGb 761 of impaired vision due to dry senile macular degeneration. Wiener Medizinische Wochenschrift 2002;152(15-16):423-6.

\section{Lebuisson 1986 \{published data only\}}

Lebuisson DA, Leroy L, Rigal G. Treatment of senile macular degeneration with Ginkgo biloba extract. A preliminary doubleblind drug vs. placebo study [Traitement des degenerescences "maculaires seniles" par l'extrait de Ginkgo biloba: etude preliminaire a double insu face au placebo]. La Press Medicale 1986;15(31):1556-8

\section{Additional references}

\section{Birks 2009}

Birks J, Grimley Evans J. Ginkgo biloba for cognitive impairment and dementia. Cochrane Database of Systematic Reviews 2009, Issue 1. [DOI: 10.1002/14651858.CD003120.pub3]

\section{Droy-Lefaix 1993}

Droy-Lefaix MT, Szabo ME, Doly M. Ischaemia and reperfusioninduced injury in rat retina obtained from normotensive and spontaneously hypertensive rates: effects of free radical scavengers. International Journal of Tissue Reactions 1993;15(2):85-91.

\section{Droy-Lefaix 1995}

Droy-Lefaix MT, Cluzel J, Menerath JM, Bonhomme B, Doly M. Antioxidant effect of a ginkgo biloba extract (EGb 761) on the retina. International Journal of Tissue Reactions 1995;17(3):93-100

\section{Evans 1996}

Evans JR, Rooney C, Dattani N, Ashwood F, Wormald RPL. Causes of blindness and partial sight in England and Wales. Health Trends 1996;28:5-12.

\section{Glanville 2006}

Glanville JM, Lefebvre C, Miles JN, Camosso-Stefinovic J. How to identify randomized controlled trials in MEDLINE: ten years on Journal of the Medical Library Association 2006;94(2):130-6.

\section{Higgins 2011}

Higgins JPT, Altman DG, Sterne JAC (editors). Chapter 8: Assessing risk of bias in included studies. In: Higgins JPT, Green S, editor(s). Cochrane Handbook for Systematic Reviews of Interventions Version 5.1.0 (updated March 2011). The Cochrane Collaboration, 2011. Available from www.cochranehandbook.org, 2011.

\section{CHARACTERISTICS OF STUDIES}

Characteristics of included studies [ordered by study ID]

\section{Hilton 2004}

Hilton M, Stuart E. Ginkgo biloba for tinnitus. Cochrane Database of Systematic Reviews 2004, Issue 2. [DOI: 10.1002/14651858.CD003852.pub2]

\section{Kleijnen 1992}

Kleijnen J, Knipschild P. Ginkgo biloba. Lancet 1992;340(8828):1136-9.

\section{Klein 1992}

Klein R, Klein BEK, Linton KL. Prevalence of age-related maculopathy. The Beaver Dam Eye Study. Ophthalmology 1992;99(6):933-43.

\section{Knipschild 1998}

Knipschild PG, Hoerr R, Oschmann R, van Rossum E, van Dongen MCJM. Optimization of placebos for doubleblind clinical trials: experience with a phytopharmaceutical. Arzneimittelforschung 1998;48(10):1033-6.

\section{Pritz-Hohmeier 1994}

Pritz-Hohmeier S, Chao TI, Krenzlin J, Reichenbach A. Effect of in vivo application of the Ginkgo biloba extract EGb 761 (Rokan) on the susceptibility of mammalian retinal cells to proteolytic enzymes. Ophthalmic Research 1994;26(2):80-6.

\section{Rosenblatt 1997}

Rosenblatt M, Mindel J. Spontaneous hyphema associated with ingestion of Ginkgo biloba extract. New England Journal of Medicine 1997;336(15):1108.

\section{Rowin 1996}

Rowin J, Lewis SL. Spontaneous bilateral subdural hematomas associated with chronic Ginkgo biloba ingestion. Neurology 1996;46(6):1775-6.

\section{Zeng 2005}

Zeng X, Liu M, Yang Y, Li Y, Asplund K. Ginkgo biloba for acute ischaemic stroke. Cochrane Database of Systematic Reviews 2005, Issue 4. [DOI: 10.1002/14651858.CD003691.pub2]

\section{References to other published versions of this review}

Evans 1999

Evans JR. Ginkgo biloba extract for. Cochrane Database of Systematic Reviews 1999, Issue 3. [DOI: 10.1002/14651858.CD001775]

* Indicates the major publication for the study 
Fies 2002

Method of allocation: validated EDP-random number generator
Masking: described as a "double blind" study
Provider: yes
10 participants from group 1 (high dose) and 3 participants from group 2 (low dose) withdrew from the
study

Country: Germany, clinic of one of the investigators
Number of participants randomised: 99
Age (years): Group 1: 74 (59 to 89), Group 2: 77 (61 to 86)
Sex: male/female 27/72
Inclusion criteria: senile dry macular degeneration
Exclusion criteria: severe co-morbidities, decompensated cardiac insufficiency; heart attack in the pre-
vious 4 weeks, pregnancy, alcohol or other substance abuse

\begin{tabular}{ll}
\hline Interventions & Two doses of Ginkgo biloba extract EGb 761 were compared: 240 mg per day versus 60 mg per day \\
& Duration of treatment: 24 weeks
\end{tabular}

\begin{tabular}{ll}
\hline Outcomes & Visual acuity; withdrawals; side-effects \\
\hline Notes & Author contacted for information about the allocation concealment \\
\hline
\end{tabular}

\section{Risk of bias}

\begin{tabular}{|c|c|c|}
\hline Bias & Authors' judgement & Support for judgement \\
\hline $\begin{array}{l}\text { Random sequence genera- } \\
\text { tion (selection bias) }\end{array}$ & Low risk & $\begin{array}{l}\text { Not clearly described in the published report but contact with the investigator } \\
\text { provided information that the allocation sequence was generated using a "val- } \\
\text { idated EDP-random number generator" }\end{array}$ \\
\hline $\begin{array}{l}\text { Allocation concealment } \\
\text { (selection bias) }\end{array}$ & Low risk & $\begin{array}{l}\text { Two different doses were compared and the study was described as "dou- } \\
\text { ble-blinded" }\end{array}$ \\
\hline $\begin{array}{l}\text { Blinding (performance } \\
\text { bias and detection bias) } \\
\text { All outcomes }\end{array}$ & Low risk & $\begin{array}{l}\text { Two different doses were compared and the study was described as "dou- } \\
\text { ble-blinded" }\end{array}$ \\
\hline $\begin{array}{l}\text { Incomplete outcome data } \\
\text { (attrition bias) } \\
\text { All outcomes }\end{array}$ & Unclear risk & $\begin{array}{l}10 \text { patients from the high dose group dropped out compared to } 3 \text { patients } \\
\text { from the low dose group however unclear how these people were analysed }\end{array}$ \\
\hline $\begin{array}{l}\text { Selective reporting (re- } \\
\text { porting bias) }\end{array}$ & Low risk & Visual acuity reported, which is a key outcome \\
\hline Other bias & Low risk & \\
\hline
\end{tabular}

Lebuisson 1986

\begin{tabular}{ll}
\hline Methods & Method of allocation: random number tables \\
& Masking: \\
& Participant: yes \\
& Provider: yes \\
& Outcome: yes \\
& Losses to follow up: none
\end{tabular}


Lebuisson 1986 (Continued)

Participants Country: France, outpatients at the Hospital Foch

Number of participants randomised: 20

Age: over 55 years, average age of 65 years (treatment) and 68 years (control)

Sex: not stated

Inclusion criteria: macular degeneration diagnosed within last year confirmed by angiography; visual acuity better than $1 / 10$

Exclusion criteria: people with (1) other ophthalmic conditions such as diabetic retinopathy, retinochoroiditis, glaucoma or maculopathy of other origin (congenital, infectious, inflammatory or myopic); (2) people where the fundus could not be seen; (3) people who were likely to undergo laser photocoagulation during the trial period

\begin{tabular}{ll}
\hline Interventions & Gingko biloba extract EGb $76180 \mathrm{mg}$ twice daily. Placebo identical in appearance, smell, and taste \\
\hline Outcomes & Distance visual acuity; near visual acuity; visual field (Friedman); clinical judgement of disease \\
\hline Notes &
\end{tabular}

\section{Risk of bias}

\begin{tabular}{lll}
\hline Bias & Authors' judgement & Support for judgement \\
\hline $\begin{array}{l}\text { Random sequence genera- } \\
\text { tion (selection bias) }\end{array}$ & Low risk & $\begin{array}{l}\text { "After the verification of the selection criteria the patients received a case } \\
\text { number that conditioned the treatment batch which they were given. An equal } \\
\text { division of the patients in to the } 2 \text { groups was made before the beginning of } \\
\text { the study with the aid of a permutation table." Translated from French publi- } \\
\text { cation. }\end{array}$ \\
\hline $\begin{array}{l}\text { Allocation concealment } \\
\text { (selection bias) }\end{array}$ & Low risk & $\begin{array}{l}\text { Allocation concealment was not specifically reported however: } \\
\text { "For the therapeutic trial, the patients were prescribed either a dose of Gingko } \\
\text { biloba extract or a placebo, both of the same appearance, same smell and } \\
\text { same taste - 2ml to be taken twice a day, ie. for the Gingko bilboa extract } 80 \mathrm{mg} \\
\text { morning and evening." Translated from French publication. }\end{array}$
\end{tabular}

Blinding (performance High risk bias and detection bias) All outcomes

\begin{abstract}
"For the therapeutic trial, the patients were prescribed either a dose of Gingko biloba extract or a placebo, both of the same appearance, same smell and same taste - $2 \mathrm{ml}$ to be taken twice a day, ie. for the Gingko biloba extract $80 \mathrm{mg}$ morning and evening." Translated from French publication.
\end{abstract}

No information was given as to the extent to which participants, their carers and people assessing outcome knew or guessed the treatment allocation. Information from study author suggests that outcome assessment was unmasked.

\begin{tabular}{|c|c|c|}
\hline $\begin{array}{l}\text { Incomplete outcome data } \\
\text { (attrition bias) } \\
\text { All outcomes }\end{array}$ & Unclear risk & $\begin{array}{l}\text { No information was provided on recruitment into the trial - data reported on } \\
20 \text { patients but not clear if more patients were recruited and whether any pa- } \\
\text { tients did not complete the trial }\end{array}$ \\
\hline
\end{tabular}

Selective reporting (re- Low risk
It was not clear from the report what the primary outcome was. Only statis- tically significant data on distance visual acuity reported in the tables. Text suggests other measures of visual function were not significantly different be- tween groups. Subjective assessment of clinical improvement reported. How- ever, as visual acuity and clinical progression are the key outcomes of this re- view, for the purposes of this review selective reporting is not likely to be a problem.

Other bias Low risk




\section{AP PE N DICES}

\section{Appendix 1. CENTRAL search strategy}

\#1 MeSH descriptor: [Macular Degeneration] explode all trees \#2 MeSH descriptor: [Retinal Degeneration] explode all trees \#3 MeSH descriptor: [Retinal Neovascularization] explode all trees \#4 MeSH descriptor: [Choroidal Neovascularization] explode all trees \#5 MeSH descriptor: [Macula Lutea] explode all trees \#6 macula* near lutea*

\#7 ${\text { (macula* } \text { or retina* }^{*} \text { or choroid }}^{\star}$ ) near/4 degenerat ${ }^{\star}$ \#8 (macula* or retina* or choroid ${ }^{\star}$ ) near $/ 4$ neovascul ${ }^{*}$ \#9 maculopath* $\# 10$ AMD or ARMD or CNV $\# 11 \# 1$ or \#2 or \#3 or \#4 or \#5 or \#6 or \#7 or \#8 or \#9 or \#10 \#12 MeSH descriptor: [Ginkgo biloba] explode all trees \#13 ginkgo* or gingko* or gingkco* or ginko* or gingho* or gincosan* \#14 bilobalid* or tebonin* or kaveri* or tanakan* or rokan* or li-1370 $\# 15 \# 12$ or \#13 or \#14

$\# 16 \# 11$ and \#15

\section{Appendix 2. MEDLINE (OvidSP) search strategy}

1. randomized controlled trial.pt.

2. (randomized or randomised).ab,ti.

3. placebo.ab,ti.

4. dt.fs.

5. randomly.ab,ti.

6. trial.ab,ti.

7. groups.ab,ti.

8. or/1-7

9. exp animals/

10. exp humans/

11.9 not (9 and 10)

12. 8 not 11

13. exp macular degeneration/

14. exp retinal degeneration/

15. exp retinal neovascularization/

16. exp choroidal neovascularization/

17. exp macula lutea/

18. maculopath\$.tw.

19. ((macul\$ or retina\$ or choroid\$) adj3 degener\$).tw.

20. ((macul\$ or retina\$ or choroid\$) adj3 neovasc\$).tw.

21. (macula\$ adj2 lutea).tw.

22. (AMD or ARMD or CNV).tw.

23. or $/ 13-22$

24. exp ginkgo biloba/

25. (ginkgo $\$$ or gingko $\$$ or gingkco $\$$ or ginko $\$$ or gingho $\$$ or gincosan $\$$ ).tw.

26. (bilobalid\$ or tebonin $\$$ or kaveri or tanakan\$ or rokan\$ or li-1370 or tanakan\$).tw.

27. or/24-26

28.23 and 27

29. 12 and 28

The search filter for trials at the beginning of the MEDLINE strategy is from the published paper by Glanville et al (Glanville 2006).

\section{Appendix 3. EMBASE (OvidSP) search strategy}

1. exp randomized controlled trial/

2. exp randomization/

3. exp double blind procedure/

4. exp single blind procedure/ 
5. random\$.tw.

6. or/1-5

7. (animal or animal experiment).sh.

8. human.sh.

9. 7 and 8

10. 7 not 9

11.6 not 10

12. exp clinical trial/

13. (clin\$ adj3 trial\$).tw.

14. ((singl\$ or doubl\$ or trebl\$ or tripl\$) adj3 (blind\$ or mask\$)).tw.

15. exp placebo/

16. placebo\$.tw.

17. random $\$$.tw.

18. exp experimental design/

19. exp crossover procedure/

20. exp control group/

21. exp latin square design/

22. or $/ 12-21$

23. 22 not 10

24. 23 not 11

25. exp comparative study/

26. exp evaluation/

27. exp prospective study/

28. (control\$ or prospectiv\$ or volunteer\$).tw.

29. or $/ 25-28$

30.29 not 10

31.30 not (11 or 23 )

32. 11 or 24 or 31

33. exp retina macula degeneration/

34. exp retina degeneration/

35. exp retina neovascularization/

36. exp subretinal neovascularization/

37. maculopath\$.tw.

38. ((macul\$ or retina\$ or choroid\$) adj3 degener\$).tw.

39. ((macul\$ or retina\$ or choroid\$) adj3 neovasc\$).tw.

40. exp retina macula lutea/

41. (macula\$ adj2 lutea\$).tw.

42. (AMD or ARMD or CNV).tw.

43. or/33-42

44. exp Ginkgo Biloba/

45. (ginkgo\$ or gingko\$ or gingkco\$ or ginko\$ or gingho $\$$ or gincosan\$).tw.

46. (bilobalid\$ or tebonin $\$$ or kaveri\$ or tanakan\$ or rokan\$ or li-1370 or tanakan\$).tw.

47. or/44-46

48. 43 and 47

49. 32 and 48

\section{Appendix 4. OpenGrey search strategy}

(ginkgo or gingko or gingkco or ginko or gingho or gincosan or bilobalid or tebonin or kaveri or tanakan or rokan or li-1370 or super-ginko) and (age related macular degeneration)

\section{Appendix 5. AMED search strategy}

1. exp ginkgo biloba/

2. (ginkgo or gingko or gingkco or ginko\$ or gingho or gincosan or bilobalid\$ or tebonin\$ or kaveri or tanakan\$ or rokan or li 1370 or

li-1370 or super-ginko\$).tw.

3. or/1-2

4. exp eye disease/

5. maculopath\$.tw.

6. ((macul\$ or retina\$ or choroid\$) adj3 degenerat\$).tw.

7. ((macul\$ or retina or choroid\$) adj3 neovasc\$).tw.

8. (AMD or ARMD or CNV).tw.

9. or/4-8

Ginkgo biloba extract for age-related macular degeneration (Review)

Copyright @ 2013 The Cochrane Collaboration. Published by John Wiley \& Sons, Ltd. 
10. 3 and 9

\section{Appendix 6. metaRegister of Controlled Trials search strategy}

(macular degeneration) AND (ginkgo or gingko or gingkco or ginko or gingho or gincosan or bilobalid or tebonin or kaveri or tanakan or rokan or li 1370 or li-1370 or super-ginko)

\section{Appendix 7. ClinicalTrials.gov search strategy}

(Macular Degeneration) AND (Ginkgo OR Gingko OR Gingkco OR Ginko OR Gingho OR Gincosan OR Bilobalid OR Tebonin OR Kaveri OR Tanakan OR Rokan OR Li 1370 OR Li-1370 OR Super-Ginko)

\section{Appendix 8. ICTRP search strategy}

macular degeneration = Condition AND ginkgo or gingko or gingkco or ginko or gingho or gincosan or bilobalid or tebonin or kaveri or tanakan or rokan or li 1370 or li-1370 or super-ginko = Intervention

\section{WHAT' S NEW}

\begin{tabular}{lll}
\hline Date & Event & Description \\
\hline 22 November 2012 & New search has been performed & Issue 1, 2013: Electronic searches were updated. \\
\hline 22 November 2012 & $\begin{array}{l}\text { New citation required but conclusions } \\
\text { have not changed }\end{array}$ & $\begin{array}{l}\text { Issue 1, 2013: No new trials were identified for inclusion in this } \\
\text { update. }\end{array}$ \\
\hline
\end{tabular}

\section{H I S T ORY}

Review first published: Issue 3, 1999

\begin{tabular}{lll}
\hline Date & Event & Description \\
\hline 14 January 2009 & New search has been performed & $\begin{array}{l}\text { Issue 2, 2009: updated search yielded no new trials. Risk of bias } \\
\text { tables have been completed for existing included studies. }\end{array}$ \\
\hline 28 August 2008 & Amended & Converted to new review format. \\
\hline 5 May 1999 & $\begin{array}{l}\text { New citation required and conclusions } \\
\text { have changed }\end{array}$ & Substantive amendment \\
\hline
\end{tabular}

\section{CONTRIBUTIONS OF AUTHORS}

The Cochrane Eyes and Vision Group editorial team prepared and executed the electronic searches.

\section{DECLARATIONS OF INTEREST}

None known.

\section{N DEX TERMS}

\section{Medical Subject Headings (MeSH)}

Ginkgo biloba [ ${ }^{\star}$ chemistry]; Macular Degeneration [ ${ }^{\star}$ drug therapy]; Phytotherapy [ ${ }^{\star}$ methods]; Plant Extracts [ ${ }^{\star}$ therapeutic use]; Randomized Controlled Trials as Topic

\section{MeSH check words}

Humans 